\title{
'Ethical' stem-cell paper under attack
}

"What we have done, for the first time, is to actually create human embryonic stem cells without destroying the embryo itself."

So stated Robert Lanza on the Nature podcast on 23 August, when his group's research paper - whose summary implied the same achievement - was published online (I. Klimanskaya et al. Nature doi:10.1038/nature05142; 2006). The paper attracted worldwide media excitement, particularly in Germany, where the law prevents scientists from working on newly derived human embryonic stem-cell lines. Shares in Lanza's company, Advanced Cell Technologies (ACT) in Worcester, Massachusetts, leapt five-fold in price in just 10 hours.

But this was quickly followed by a backlash as it became clear that all 16 of the embryos used in the research had been destroyed. German newspapers, for example, accused Lanza, as well as Nature, of hyping the results.

"So many things about the paper and how it was presented are unclear," complains stem-cell scientist Hans Schöler, a director of the Max Planck Institute for Molecular Biomedicine in Münster, Germany. Schöler says he is disappointed that such confusion should cloud the field so soon after the Woo Suk Hwang scandal, in which the South Korean scientist falsely claimed to have created embryonic stem-cell lines from cloned human embryos.

No one is suggesting that Lanza's paper is in any way scientifically incorrect, but many in the field have objected, like Schöler, to its overall packaging. "Perhaps 'word-smithy' is the right term," comments George Daley of the Harvard Stem Cell Institute.

As well as the comments on the podcast, the paper's abstract also implied that the ACT scientists had created stem-cell lines without destroying embryos, saying: "The ability to create new stem-cell lines and therapies without destroying embryos would address the ethical concerns of many." Nature's press release also stated that only one cell had been taken from each embryo - a misconception repeated in subsequent news stories.

The paper itself, however, shows only proof of principle that a human embryonic stem-cell line can be created from a single cell, or blastomere, from a very early embryo comprising 8-10 cells. None of the embryos used survived. The Nature paper's details and Supplementary Information made clear that all the embryos were broken up, stating that 91 cells were used from 16 embryos. Only two stem-cell lines were created,

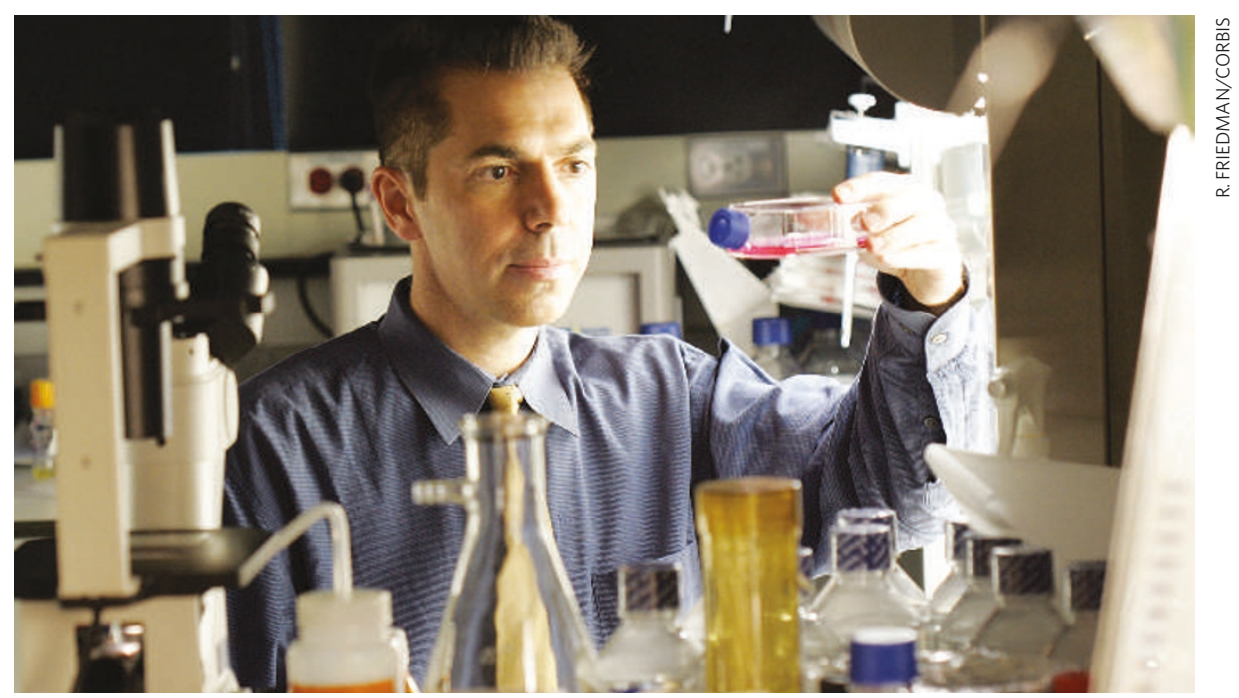

Robert Lanza believes his human embryonic stem-cell research will resolve ethical concerns.

so the efficiency of the process - barely $2 \%$ - is much lower than it appears to be at first glance.

Some feel this caveat was hidden too deeply. Peter Andrews of the University of Sheffield, UK, co-leader of ESTOOLS, the European Union's programme to develop human embryonic stem-cell biology, says that researchers as well as journalists were fooled: "Many scientists at the kick-off meeting of ESTOOLS a couple of days later had quickly read the manuscript and got the impression that Lanza really had extracted just a single cell, and that the embryos survived."

Within minutes of the paper going live, Nature's press office corrected its press release to say that Lanza's experiments had destroyed some of the embryos. Two days later, a second note made clear that all the embryos had been destroyed. "Nature takes responsibility for the problems with the press release, for which I apologize," says Philip Campbell, editor-in-chief of Nature. He adds that a clarification has been posted alongside Nature's podcast, and that the paper will also be clarified.

Lanza says he never intended to say more than that he had proved a principle, and that he is surprised by the reaction to the paper. $\mathrm{He}$ adds that the established procedure of pre-implantation genetic diagnosis (PGD), in which a single cell is extracted for genetic analysis, has already shown that embryos from which a blastomere has been removed survive. "We knew that, so we took multiple cells from each embryo so as not to be wasteful," he says.
The Nature paper says Lanza's method will "allow the generation of matched tissue for children and siblings born from transferred PGD embryos", and he now plans to take the work into the clinic. He hopes the methodology will provide a source of stem cells compatible with US law, which prohibits public funding of research into new human embryonic cell lines derived at the expense of embryos.

Many stem-cell researchers describe the science in Lanza's paper as interesting, if preliminary. "Anything that you learn about human stem-cell biology, is going to be helpful, whatever way you want to derive new cell lines," comments Daley. But it is still not clear whether applying this approach to PGD embryos would resolve ethical concerns (see Nature 442, 858; 2006). Norio Nakatsuji of Kyoto University, who derived Japan's only human embryonic stem-cell lines, points out that the process poses a small risk to the baby. "We don't know how this would be legally interpreted," adds James Battey, chair of the US National Institutes of Health (NIH) Stem Cell Task Force. "The NIH would need a test case."

Scientists in countries where cell lines may be legally derived from embryos discarded from in vitro fertilization procedures, such as Britain, Sweden and Japan, also object to the idea of carrying out research just to get round political restrictions. "It is more ethical to work on embryos that are going to be destroyed anyway," says Andrews. "If you do science for the purpose of getting around the law it makes things worse; it makes science look dishonest."

Alison Abbott 